\title{
Integrin up-regulation as marker of neuroblastoma cell differentiation: correlation with neurite extension
}

\author{
Carla Rozzo*, Valeria Chiesa and Mirco Ponzoni ${ }^{1}$ \\ ${ }^{1}$ Laboratory of Oncology, G. Gaslini Children's Hospital, Genoa \\ Present address: *Molecular Genetics Institute, National Research Council, \\ Alghero, Italy \\ 1 corresponding author: Mirco Ponzoni, Laboratory of Oncology, G. Gaslini \\ Children's Hospital, Largo G. Gaslini, 5-16147 Genoa, Italy. \\ tel: +39 105636 342; fax: 39103776590
}

Received 29.11.96; revised 3.2.97; accepted 16.7.97

Edited by M Noble

\begin{abstract}
We have characterized the adhesion properties, integrin expression, and morphological changes due to extracellular matrix (ECM)-integrin interactions in a neuronal model. We showed that a modulation of some integrin heterodimers occurs during interferon- $\gamma$ (IFN- $\gamma$ ) induced neuroblastoma (NB) cell differentiation. To better elucidate the possible implication and function of integrin receptors during neuronal maturation, we analyzed the changes in integrin expression in two human NB cell lines, LAN-5 and GI-LI-N, which represent different stages of neuronal differentiation. These models show opposite morphological maturation after interferon- $\gamma$ and tumor necrosis factor- $\alpha$ (IFN- $\gamma+$ TNF) treatment. While LAN- 5 cells acquired the ability to extend long and branched neurites, GI-LI-N cells did not. Both cell lines showed enhanced expression of phenotypical and biochemical markers of neural maturation. Moreover, retinoic acid (RA) had different effects on the two NB cell lines: on LAN- 5 cells it acts as a differentiation-promoting agent, while on GI-LI-N cells it has an antiproliferative effect, driving them to apoptosis. RT-PCR experiments and immunoprecipitation assays showed a late but marked increase in the expression of $\alpha_{1}, \alpha_{2}, \alpha_{3}$, and $\beta_{1}$ chains after IFN- $\gamma+$ TNF treatment of LAN-5 cells, and only $\alpha_{1}$ and $\beta_{1}$ chains upon RA induction. Treatment with IFN- $\gamma+$ TNF induced GI-LI-N cells to show only a late and remarkable increase of $\alpha_{1} / \beta_{1}$ heterodimer; on the contrary, RA treatment caused a decrease in all integrin chains. These changes are accompanied in differentiated cells by substantial increases in cell attachment to all purified ECM components tested and an increase of neurite-bearing cells and of average neurite length. In conclusion, these findings indicate a close correlation between up-regulation of integrins and neuronal morphogenesis.
\end{abstract}

Keywords: neuroblastoma; retinoic acid; interferon- $\gamma$; differentiation; integrins; neuritogenesis
Abbreviations: ECM, extracellular matrix; IFN- $\gamma$, interferon- $\gamma$; NB, neuroblastoma; TNF, tumor necrosis factor $-\alpha$; RA, retinoic acid; TNF-Rs, TNF receptors; NFs, neurofilaments, $\mathrm{MAP}_{2}$ $\operatorname{MAP}_{5} \operatorname{MAP}(\tau)$, microtubule-associated proteins 2,5, $(\tau)$; GAPDH, glyceraldehyde-3-phosphate-dehydrogenase

\section{Introduction}

Integrins are the major family of cell surface receptors that mediate cell-to-cell and cell-to-extracellular matrix (ECM) interactions (Hynes, 1992). These integrin-mediated adhesive interactions are intimately involved in the regulation of many cellular functions, including embryonic development, homeostasis, leukocyte homing and activation, angiogenesis, tumor cell growth and metastasis (Juliano and Haskill, 1993; Stoker et al, 1968; Adams and Watt, 1993; Brooks et al, 1994; Blau et al, 1991). Indeed, intracellular contacts and cell-matrix interactions profoundly effect phenotypic features, such as gene regulation, cytoskeletal structure, cell growth control, and differentiation (Blau and Baltimore, 1991; Frisch and Francis, 1994; Ingber, 1993). Moreover, integrins are the major class of adhesion receptors in the nervous system, mediating the differentiating effects of ECM components on neural cells during development (Reichardt and Tomaselli, 1991).

Neuroblastoma (NB) is the most common extracranial malignant solid tumor of childhood arising from the sympathetic nervous system (De Bernardi et al, 1987). Although NB cells are presumably derived from a common transformed progenitor (Tsokos et al, 1987), they usually express multiple phenotypes, including the neuronal, neurilemmal, ephitelioid, and melanocytic ones (Tsokos et al, 1987; Biedler et al, 1973). All phenotypes may interconvert in vitro either spontaneously or in a tissue culture condition-dependent manner (Ross et al, 1983; Ciccarone et al, 1989). A variety of drugs and biological agents have been reported to induce differentiation of NB cells in vitro (Abemayor and Sidell, 1989; Lanciotti et al, 1992; Ponzoni et al, 1992). Therefore, NB cell lines are suitable models for investigating the mechanisms of neuronal death and their relation to differentiation (Piacentini et al, 1992; Ponzoni et al, 1995; Hanada et al, 1993). Moreover, treatment-induced maturation has been well documented in some patients, similarly resulting in differentiation primarily along neural crest, neuronal and Schwannian cell lineages. Thus, this neural crest-derived tumor retains its ability to differentiate along physiological lineages for an adrenal medullary precursor cell, including the chromaffin and non-chromaffin lineages present in the adult adrenal medulla (Tsokos et al, 1987; Ciccarone et al, 1989; Abemayor and Sidell, 1989). Although the two human NB cell lines, GI-LI-N and LAN-5, used in this study as a well-defined model system (Abemayor and Sidell, 1989; Ponzoni et al, 1992, 1995; Montaldo et al, 1994), represent 
different stages of chromaffin maturation of the adrenal medulla (Cooper et al, 1990a,b), they are both inducible along neuronal cell lineage using interferon- $\gamma$ (IFN- $\gamma$ ) plus tumor necrosis factor- $\alpha$ (TNF) (Ponzoni et al, 1992; Montaldo et al, 1994).

The expression of integrins can be regulated by growth and differentiation factors (Dedhar et al, 1991; Heino et al, 1989). Indeed, the expression of certain integrins may be crucial for a differentiating phenotype (Menko and Boettiger, 1987) and consequently the expression of different integrins may be up- or down-regulated according to the differentiation state of a given cell (Dedhar et al, 1989).

Recently, we have also shown that integrin heterodimers are modulated during human NB cell differentiation (Rozzo et al, 1993) To further investigate the role of integrins in cell-type specific differentiation, and since NB cell adhesion to matrix is an absolute requirement for survival, proliferation or differentiation, we reasoned that modulation of their adhesion capability may represent a signal to activate a differentiation process in these cells, or alternatively may be a marker of ongoing differentiation, correlating with the process of neuritogenesis. Our results demonstrate that ECM, acting through integrin receptors, directs already committed NB cells to establish and maintain the differentiated state, regulating their neurite outgrowth capability.

\section{Results}

\section{Effects of various biological agents on NB cell maturation}

The hallmarks of NB cell differentiation in vitro following treatment with a variety of compounds or biological agents have been described in detail (Abemayor and Sidell, 1989; Ponzoni et al, 1992; Wuarin et al, 1991). Although the changes observed vary broadly among the different cell lines and inducing treatments, the general features of NB cell differentiation include slowing or complete arrest of proliferation, loosening of cell cluster and emission of neuritic processes. Moreover, a series of biochemical changes involving cytoskeletal proteins, membrane antigens and neurotransmitters biosynthetic pathways takes place. Morphological changes and expression of mature cytoskeletal proteins have been checked in the present study to assess cell differentiation.

Morphological evaluation The phenotypic characteristics of NB cell lines were evaluated by microscopic analysis of their morphology after 5 days of treatment. Treatment of LAN-5 cells with IFN- $\gamma$ alone or in combination with TNF or with the addition of RA resulted in marked differentiation toward the neuronal phenotype. Cells appeared to be more spread out and polar, more adherent, with longer and interconnected neurites (Figure 1C, E, and I, respectively). TNF alone did not induce any morphological change (Figure 1G) in LAN-5 cells because the latter cells constitutively do not express TNF-Rs, while the p80 form of TNF-R is induced by IFN- $\gamma$ treatment (Montaldo et al,
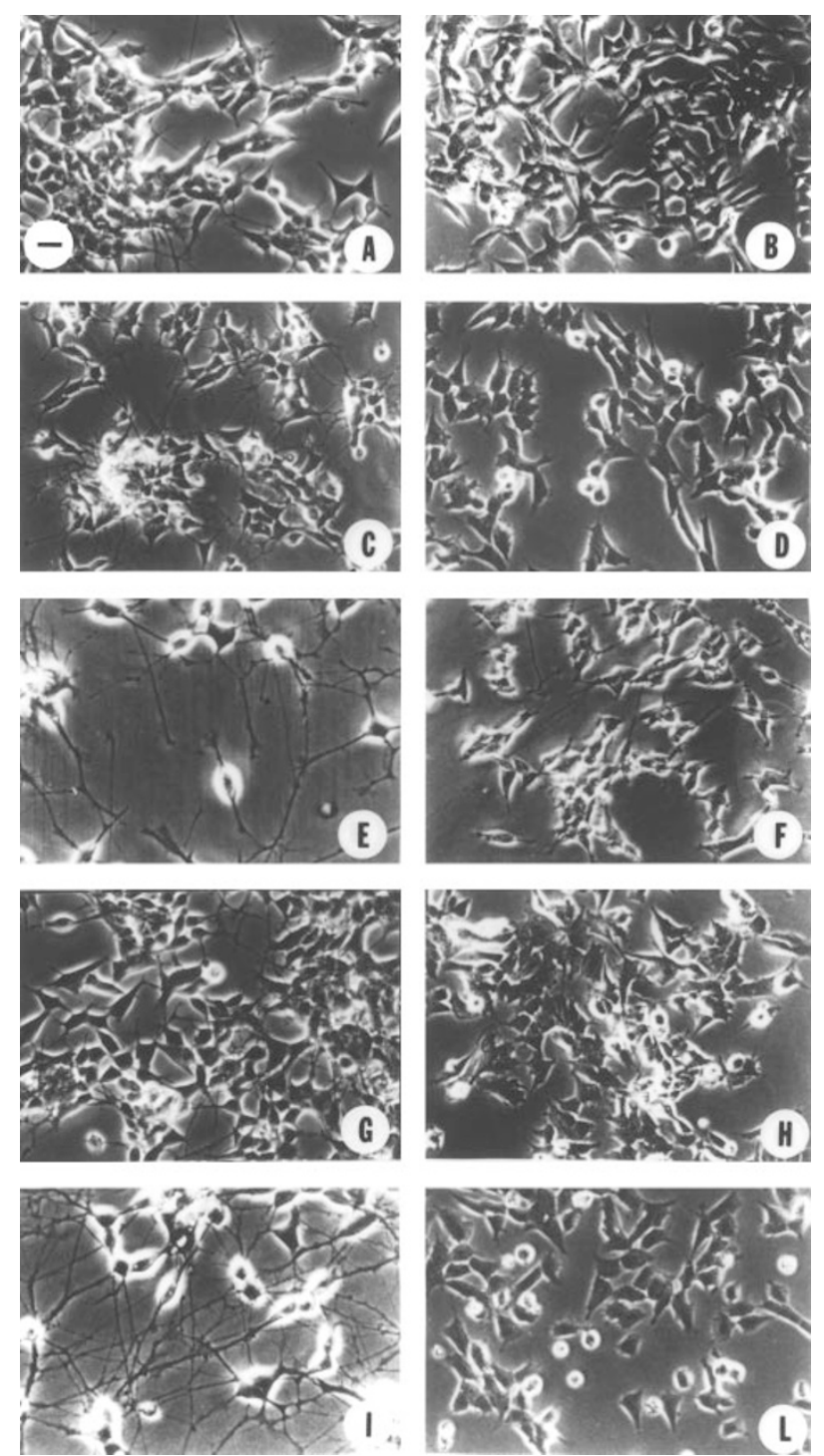

Figure 1 Morphological changes induced by differentiating treatments in LAN-5 (left side of the panel) and GI-LI-N (right side of the panel) NB cells. Phase contrast micrographs, bar $75 \mu \mathrm{m}$. (A, B) control cells; (C, D) cells cultured in the presence of $1000 \mathrm{IU} / \mathrm{ml} \mathrm{IFN-} \gamma$; (E, F) $1000 \mathrm{IU} / \mathrm{ml} \mathrm{IFN-} \gamma$ plus $200 \mathrm{IU} / \mathrm{ml} \mathrm{TNF}$ (G, H) $200 \mathrm{IU} / \mathrm{ml}$ TNF; (I, L) $3 \times 10^{-6} \mathrm{MRA}$.

1994). A less pronounced morphological differentiation was noted in GI-LI-N cells. Although also this cell line expresses IFN- $\gamma-\mathrm{R}$ (Montaldo et al, 1994), it seems almost insensitive to IFN- $\gamma$ in terms of morphological maturation (Figure 1D). However, the synergistic effect of IFN- $\gamma$ and TNF (Figure 1F) caused the appearance of a minor population of large flattened epithelial-like cells (also observed in TNF-treated cells, Figure $1 \mathrm{H}$ ) among a majority of small spindle-shaped cells with elongated short neuritic processes, similar to those observed in cells treated with IFN- $\gamma$ alone (Figure 1D).

By contrast, GI-LI-N cells treated with RA rounded up, reduced their diameter and eventually detached from the dish (Figure 1L). The same morphological features were observed by microscopy of May Grünwald-Giemsa-stained 


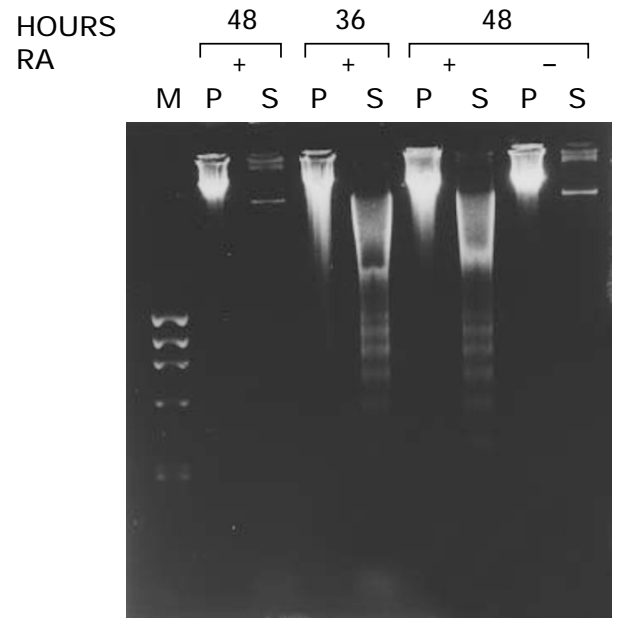

GI-LI-N

Figure 2 Time-dependent induction of DNA fragmentation by RA-treatment of GI-LI-N cells. NB cells $\left(1 \times 10^{6}\right.$ cells/time point) either untreated $(-)$ or treated with $3 \times 10^{-6} \mathrm{MRA}(+)$ were lysed and the DNA was isolated and electrophoresed as described in the Materials and Methods section. $(P)$ pellets of intact DNA; (S) supernatants containing fragmented DNA; (M) Haellldigested $\phi \chi$ DNA as molecular size marker.

cells (data not shown). Thus, the morphology of GI-LI-N cells following RA treatment may be due to programmed cell death rather than to necrosis and/or terminal differentiation (Piacentini et al, 1992; Ponzoni et al, 1995; Thompson, 1995; Rozzo et al, 1997). This hypothesis has been confirmed by electrophoretic analysis. Indeed, as shown in Figure 2 the characteristic pattern of DNA fragmentation in multiples of $180-200 \mathrm{bp}$ was observed in GI-LI-N cells starting from $36 \mathrm{~h}$ of treatment with $3 \times 10^{-6}$ M RA.

Cytoskeletal protein modulation Expression of cytoskeletal proteins by treated and control LAN- 5 and GI-LI-N cells was investigated by immunofluorescence analysis of permeabilized cells. A representative panel of photomicrographs of NB cells stained with some mAbs to cytoskeletal proteins is shown in Figure 3, while the overall results are summarized in Table 1 . The high molecular weight NFs and, in particular, their phosphorylated forms were up-modulated in both NB cell lines by treatment with the combination of IFN- $\gamma$ and TNF, with a shift in fluorescence localization from a diffuse somatic to an intense perinuclear and neuritic pattern. By contrast, RA treatment induced a marked increase of NFs in LAN-5 cells, while it induced a faint decrease of these cytoskeletal proteins in GI-LI-N cells. As for NFs, treatment of NB cells with IFN- $\gamma+$ TNF induced a drastic enhancement in the expression of $\mathrm{MAP}_{2}, \mathrm{MAP}_{5}$, and MAP $(\tau)$ with a sharp immunolocalization in the perinuclear and neuritic compartments. As expected, treatment with RA increased the expression of MAPs in LAN-5 cells, while it induced a modest down-modulation in GI-LI-N cells, further indicating the inability of RA to trigger neuronal differentiation in this cell line.

\section{Modulation of integrin expression during NB cell differentiation}

Recently, we (Rozzo et al, 1993) and others (Rossino et al, 1991) have shown that modulation of some integrin heterodimers occurs during NB cell differentiation. To better elucidate the possible implication and function of these integrins during neuronal maturation, we analyzed the changes in integrin expression in LAN-5 and GI-LI-N cell lines, which represent different stages of neuronal differentiation (Cooper et al, 1990a,b). To this end, both NB cell lines were treated with IFN- $\gamma$, IFN- $\gamma+T N F$, or RA, total RNA was extracted at different time intervals and utilized for the evaluation of integrin mRNA expression by RT-PCR. Oligonucleotide primers specific for $\alpha_{1}, \alpha_{2}, \alpha_{3}$, and $\beta_{1}$ integrin chains were used and the results are shown in Figure 4A, B and C. Treatment with IFN- $\gamma$ induced a late but consistent up-regulation of all integrin chains in LAN-5 cells, responsive to IFN- $\gamma$ in terms of differentiation capability, while no significant changes were observed in IFN- $\gamma$-resistant GI-LI-N cells. Treatment of both cell lines with the combination of IFN- $\gamma+\mathrm{TNF}$, that appears to promote biochemical and functional changes associated with differentiation of both NB cell lines, drastically enhanced the mRNA expression for all integrin chains with time. As expected from the biological studies, we did not observe any changes in TNF-treated cells. By contrast, opposite effects were observed in the two cell lines after treatment with RA. Indeed, a clear up-regulation of the $\alpha_{1}$ and $\beta_{1}$ mRNAs expression was detected after 3 days of treatment in LAN-5 cells, that are also induced into terminal differentiation, while an early and drastic down-modulation of all integrin chains was obtained in GI$\mathrm{LI}-\mathrm{N}$ cells, that are driven to apoptotic cell death by RA (Rozzo et al, 1997).

The pattern of expression of the corresponding protein products after 5 days of treatment was then analyzed by immunoprecipitation of lysates from treated and untreated surface radioiodinated NB cells (Figure 5). Using an antiserum to the $\beta_{1}$ chain, we co-immunoprecipitated both $\beta_{1}$ chain and the associated $\alpha$ chains with the following molecular weights: $\beta_{1} 110 \mathrm{Kda}, \alpha_{2}$ and $\alpha_{3}$ $150 \mathrm{Kda}, \alpha_{1} 200 \mathrm{Kda}$ (Rozzo et al, 1993; Rossino et al, 1991; and Figure 5). These results have been confirmed using specific monoclonal antibodies to the various $\alpha$ chains (data not shown and Rozzo et al, 1993; Rossino et al, 1991). A significant enhancement of the $\alpha_{1} \beta_{1}, \alpha_{2} \beta_{1}$, and $\alpha_{3} \beta_{1}$ heterodimers was seen in both cell lines treated with the combination of IFN- $\gamma+$ TNF. A similar increase was observed in IFN- $\gamma$-treated LAN-5 cells, while no integrin increase was visible when treated with TNF alone. Moreover, in cells in which the proliferation rate was arrested by starvation with $2 \%$ FCS-containing medium without affecting cell maturation (Lanciotti et al, 1992; Rozzo et al, 1993), the amounts of such integrins were comparable to those seen in untreated cells. Finally, following treatment with RA, a very marked increase of the $\alpha_{1} \beta_{1}$ heterodimer was seen in LAN-5 cells, while a drastic down-modulation of integrin expression was observed in GI-LI-N cells. We 

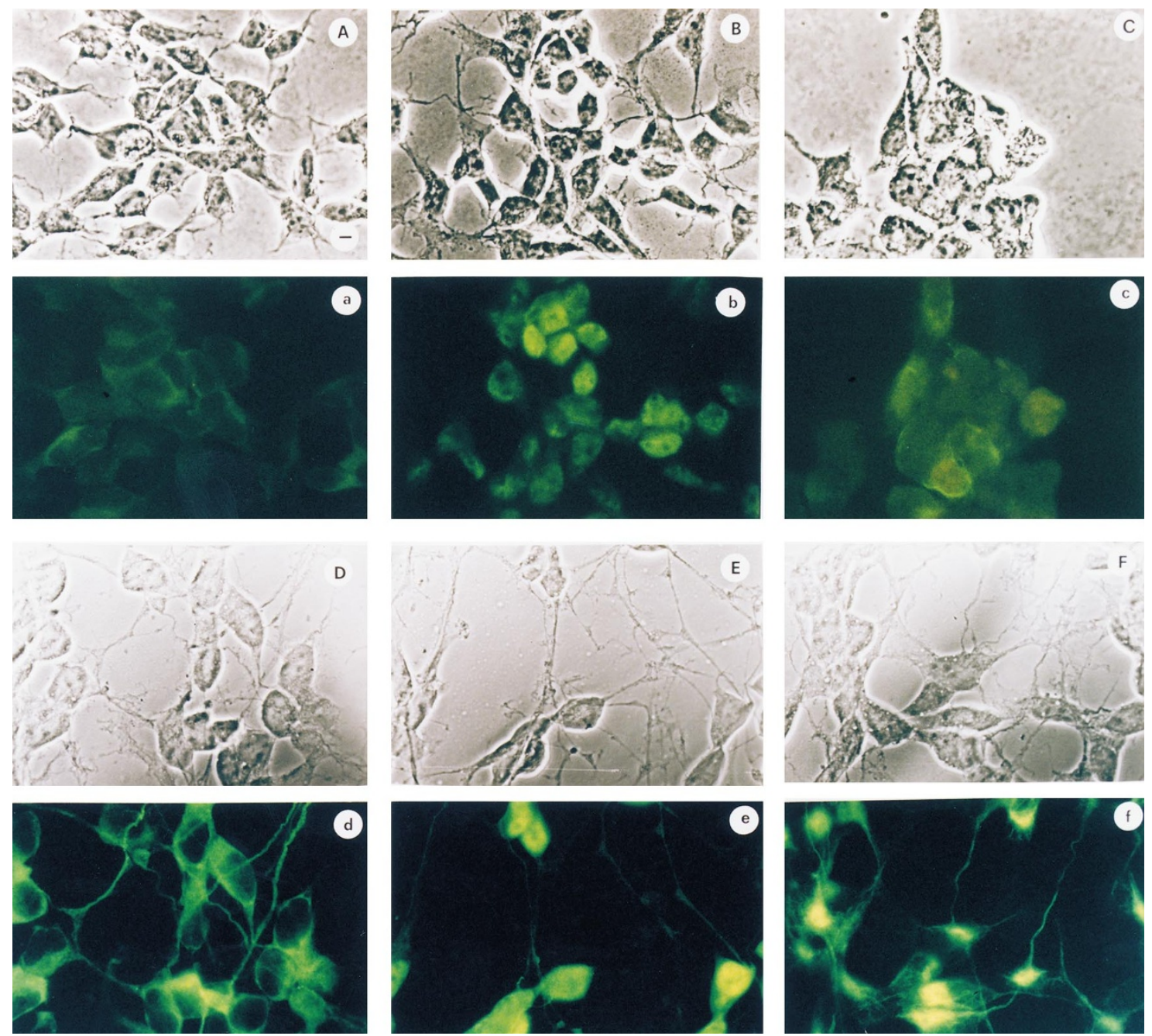

Figure 3 Immunofluorescence analysis of cytoskeletal proteins in LAN-5 cells. NB cells were untreated $(A, a, B, b, C, c)$ or treated for 5 days $(D, d, E, e, F, f)$ with IFN$\gamma+$ TNF and analyzed by fluorescence microscopy after staining with mAbs to MAP-5 (a,d), NF-200 Kda (b,e) and NF-200 Kda-P (c,f). Phase contrast pictures of the same fields $(A, B, C, D, E, F)$. bar $=20 \mu \mathrm{m}$.

then investigated the time-dependence of these modulations by performing immunoprecipitation experiments at earlier times. In agreement with RT-PCR data, we did not observe any protein modulation before 2-3 days of treatment with the various differentiation protocols (data not shown).

\section{Modulation of NB cell adhesion during differentiation}

To assess the biological significance of these integrin modulations, we performed cell adhesion assays after 5 days of treatment. As shown in Figure 6, differentiation protocols induced a drastic enhancement in the attachment of LAN-5 cells to the most important ECM proteins. As expected, treatment with IFN- $\gamma+$ TNF increased the ability of GI-LI-N cells to attach to ECM proteins, while RA treatment decreased the percentage of adhesion of these cells.
When testing the precocity of the effects of the differentiating agents, we did not observe early upmodulation of NB cell adhesion (Figure 7), Indeed, although the changes detected vary between the two NB cell lines, the inducing treatments and, overall, the ECM proteins tested, we generally observed a timedependent up-regulation of cell attachment starting from 48-72 $\mathrm{h}$ after RA- and IFN- $\gamma+$ TNF-treatments, thus confirming the data obtained by RT-PCR and immunoprecipitation.

Since biochemical features of NB cell differentiation are already detectable after 2 days of treatment with the differentiation promoting agents (Lanciotti et al, 1992; Ponzoni et al, 1992; Montaldo et al, 1994), these findings clearly indicate a role for integrin receptors in neuronal morphogenesis thus ruling out their possible involvement in the triggering of NB cell maturation.

This conclusion was confirmed by the fact that when differentiated LAN-5 cells were plated on ECM proteins, 
Table 1 Effects of various differentiation-promoting agents on cytoskeletal proteins of LAN-5 and GI-LI-N human NB cells assessed by immunofluorescence analysis after 5 days

\begin{tabular}{|c|c|c|c|c|c|}
\hline Treatment & NF-200 Kda & NF-200 KDa-P & MAP2 & MAP5 & $\tau$ \\
\hline $\begin{array}{l}\text { LAN-5 cells } \\
\text { Control }\end{array}$ & $\begin{array}{c}78 \pm 8^{a} \\
++{ }^{b} \\
S^{c}\end{array}$ & $\begin{array}{c}45 \pm 4 \\
+ \\
S, P\end{array}$ & $\begin{array}{c}58 \pm 8 \\
+ \\
S, P\end{array}$ & $\begin{array}{c}55 \pm 4 \\
+ \\
S, P\end{array}$ & $\begin{array}{c}19 \pm 6 \\
+ \\
S\end{array}$ \\
\hline $\mathrm{IFN}-\gamma(1000 \mathrm{U} / \mathrm{ml})$ & $\begin{array}{c}92 \pm 7 \\
++ \\
\text { S,P,N }\end{array}$ & $\begin{array}{c}80 \pm 10 \\
++ \\
P, N\end{array}$ & $\begin{array}{c}90 \pm 6 \\
++ \\
S, P\end{array}$ & $\begin{array}{c}82 \pm 8 \\
++ \\
S, P, N\end{array}$ & $\begin{array}{c}69 \pm 5 \\
++ \\
S, P, N\end{array}$ \\
\hline TNF $(200 \mathrm{U} / \mathrm{ml})$ & $\begin{array}{c}70 \pm 3 \\
++ \\
S\end{array}$ & $\begin{array}{c}44 \pm 7 \\
+ \\
S, P\end{array}$ & $\begin{array}{c}59 \pm 6 \\
+ \\
S, P\end{array}$ & $\begin{array}{c}58 \pm 6 \\
+ \\
S, P\end{array}$ & $\begin{array}{c}20 \pm 5 \\
+ \\
s\end{array}$ \\
\hline $\begin{array}{l}\text { INF- } \gamma(1000 \mathrm{U} / \mathrm{ml})+ \\
\operatorname{TNF}(200 \mathrm{U} / \mathrm{ml})\end{array}$ & $\begin{array}{c}94 \pm 6 \\
+++ \\
\mathrm{S}, \mathrm{P}, \mathrm{N}\end{array}$ & $\begin{array}{c}90 \pm 5 \\
+++ \\
P, N\end{array}$ & $\begin{array}{c}93 \pm 7 \\
+++ \\
\text { S,P }\end{array}$ & $\begin{array}{c}91 \pm 7 \\
++ \\
P, N\end{array}$ & $\begin{array}{c}82 \pm 5 \\
+++ \\
S, P, N\end{array}$ \\
\hline $\mathrm{RA}\left(3 \times 10^{-6} \mathrm{M}\right)$ & $\begin{array}{c}92 \pm 5 \\
++ \\
S, P, N\end{array}$ & $\begin{array}{c}83 \pm 8 \\
+++ \\
P, N\end{array}$ & $\begin{array}{c}79 \pm 6 \\
++ \\
S, P, N\end{array}$ & $\begin{array}{c}93 \pm 7 \\
++ \\
P, N\end{array}$ & $\begin{array}{c}60 \pm 8 \\
++ \\
P, N\end{array}$ \\
\hline $\begin{array}{l}\text { GI-LI-N cells } \\
\text { Control }\end{array}$ & $\begin{array}{c}80 \pm 9 \\
+ \\
S\end{array}$ & $\begin{array}{c}35 \pm 7 \\
+ \\
S, P\end{array}$ & $\begin{array}{c}60 \pm 8 \\
+ \\
S\end{array}$ & $\begin{array}{c}43 \pm 5 \\
+ \\
S, P\end{array}$ & $\begin{array}{c}32 \pm 6 \\
+ \\
S\end{array}$ \\
\hline $\mathrm{IFN}-\gamma(1000 \mathrm{U} / \mathrm{ml})$ & $\begin{array}{c}88 \pm 6 \\
+ \\
S, P\end{array}$ & $\begin{array}{c}48 \pm 5 \\
+ \\
S, P\end{array}$ & $\begin{array}{c}68 \pm 6 \\
+ \\
S, P\end{array}$ & $\begin{array}{c}49 \pm 7 \\
+ \\
\text { S,P }\end{array}$ & $\begin{array}{c}39 \pm 4 \\
+ \\
S, P\end{array}$ \\
\hline TNF $(200 \mathrm{U} / \mathrm{ml})$ & $\begin{array}{c}90 \pm 8 \\
+ \\
S, P\end{array}$ & $\begin{array}{c}44 \pm 6 \\
+ \\
\text { S,P }\end{array}$ & $\begin{array}{c}73 \pm 4 \\
+ \\
\text { S,P }\end{array}$ & $\begin{array}{c}50 \pm 4 \\
+ \\
S, P\end{array}$ & $\begin{array}{c}42 \pm 7 \\
+ \\
\text { S,P }\end{array}$ \\
\hline $\begin{array}{l}\text { IFN- } \gamma(1000 \mathrm{U} / \mathrm{ml})+ \\
\operatorname{TNF}(200 \mathrm{U} / \mathrm{ml})\end{array}$ & $\begin{array}{c}93 \pm 7 \\
++ \\
\text { S,P }\end{array}$ & $\begin{array}{c}57 \pm 5 \\
++ \\
S, P, N\end{array}$ & $\begin{array}{c}94 \pm 6 \\
++ \\
\text { S,P }\end{array}$ & $\begin{array}{c}56 \pm 5 \\
++ \\
S, P, N\end{array}$ & $\begin{array}{c}72 \pm 6 \\
++ \\
\text { S,P }\end{array}$ \\
\hline $\mathrm{RA}\left(3 \times 10^{-6} \mathrm{M}\right)$ & $\begin{array}{c}70 \pm 7 \\
+ \\
S\end{array}$ & $\begin{array}{c}21 \pm 4 \\
+ \\
S\end{array}$ & $\begin{array}{c}50 \pm 9 \\
+ \\
\mathrm{S}\end{array}$ & $\begin{array}{c}28 \pm 5 \\
+ \\
S\end{array}$ & $\begin{array}{c}22 \pm 5 \\
+ \\
S\end{array}$ \\
\hline
\end{tabular}

aPercent of positive cells. Data are the means \pm SD of three independent experiments. ${ }^{\text {b}}$ Fluorescence intensity: + , weakly positive;,++ moderately positive;,+++ strongly positive. ${ }^{C}$ Fluorescence localization: $S$, somatic; $\mathrm{P}$, perinuclear; $\mathrm{N}$, neuritic

there was a great increase in their capacity to extend neurites with respect to untreated cells (Figure 8). In keeping with the working hypothesis, the fraction of neurite-bearing cells and mean neurite length increased with 2 days of IFN- $\gamma+$ TNF treatment of both NB cell lines, when cells were plated for $12 \mathrm{~h}$ over culture dishes coated with collagen I (Table 2). Similar results were obtained when differentiated NB cells were plated on collagen IV and laminin (data not shown).

\section{Discussion}

The results presented in this paper are consistent with the interpretation that ECM, acting through integrin receptors, directs committed NB cells to establish and maintain the differentiated state.

NB is a peculiar tumour in its behavior inasmuch as it can occasionally undergo in vivo spontaneous or chemically-induced maturation or regression (Hass, 1988). One mechanism of tumour regression probably involves maturation of neoplastic cells into terminally differentiated, nonproliferating, ganglion-like cells (Cushing and Wolbach,
1927). A second mechanism, closely associated with differentiation and reported even for non-neuronal models (Hanada et al, 1993; Jensen et al, 1992) may involve the induction of programmed cell death.

Several reports have shown that retinoids have antitumor properties. Besides the well known differentiation-inducing ability of RA (Abemayor and Sidell, 1989; Sidell, 1982), it has recently been reported that RA can induce programmed cell death in neuronal models, depending on the phenotype of NB cells used (Piacentini et al, 1992), or can induce terminal differentiation followed by apoptosis independently of the cellular phenotype (Ponzoni et al, 1995). Thus, we investigated the effects of RA in two human, stage unrelated, neuroblastic-like NB cell lines in comparison with those of the combination of IFN$\gamma+$ TNF, which induce terminal differentiation of NB cells (Ponzoni et al, 1992; Montaldo et al, 1994). We found that RA completely differentiated LAN-5 cells, while it did not induce any morphological change or cytoskeletal protein modulation, typical of neuronal maturation in GI-LI-N cells. On the contrary, it drove GI-LI-N cells to programmed cell death (Rozzo et al, 1997). Moreover, the combination of 


$$
\text { LAN }-5 \text { cells }
$$
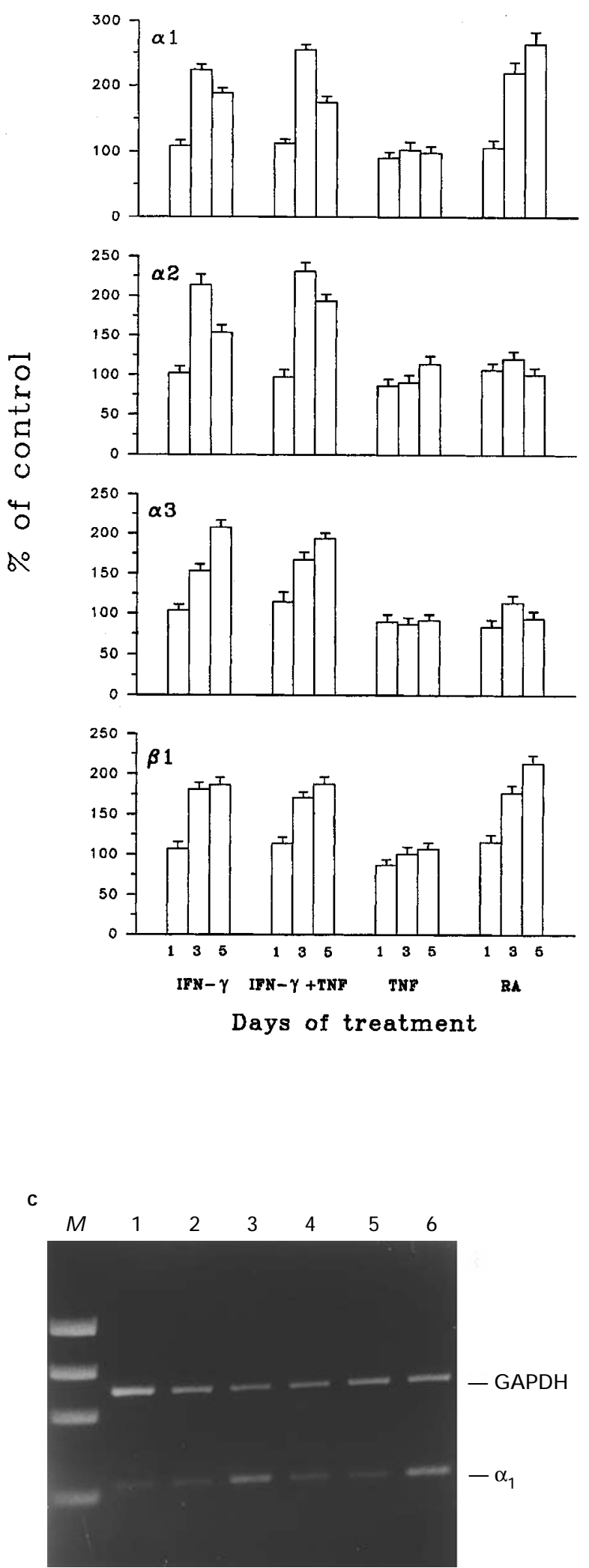

$$
\text { GI-LI-N cells }
$$
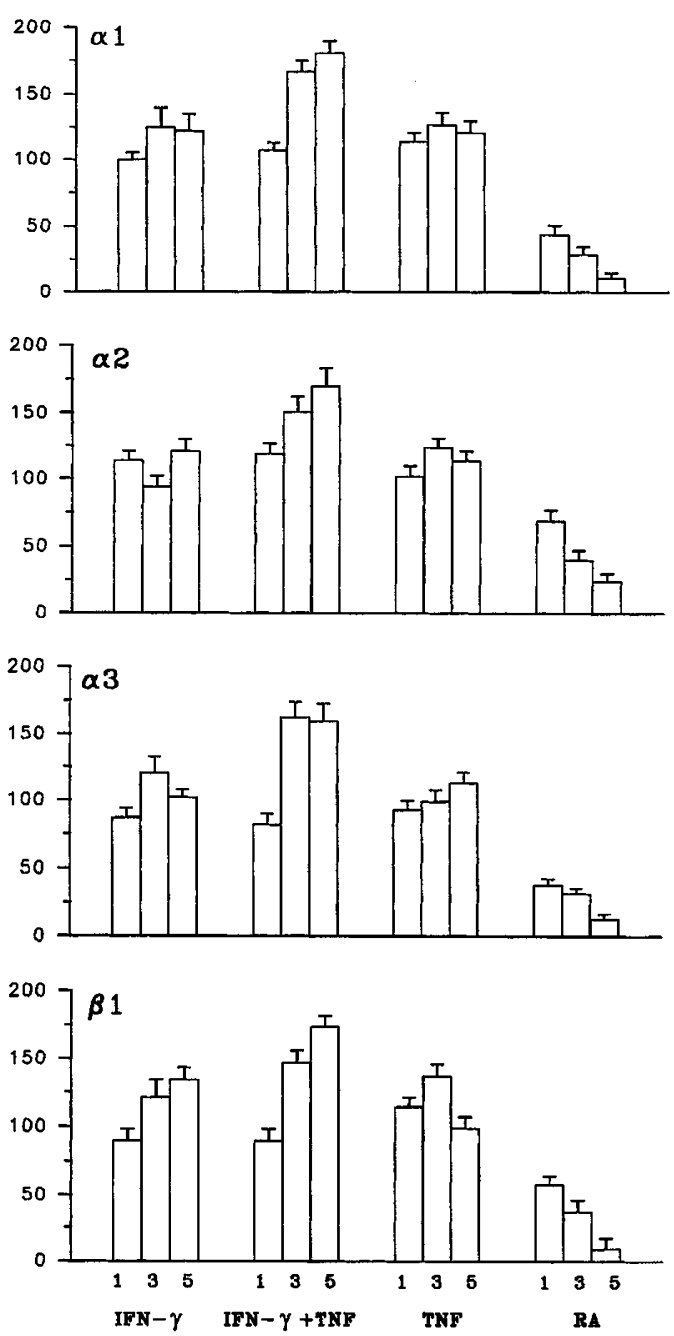

Days of treatment

Figure 4 Expression of $\alpha_{1}, \alpha_{2}, \alpha_{3}$ and $\beta_{1}$ mRNAs during differentiation of LAN-5 and GI-LI-N cells. The data are obtained by densitometric scanning (A and $\mathbf{B}$ ) of RT - PCR products analyzed by agarose gel electrophoresis using the AppleScan program. Different integrins and the housekeeping gene GAPDH were coamplified by RT-PCR of total RNA from control and treated LAN-5 (A) or GI-LI-N (B) cells. The data are calculated as the ratio between the optical density of the integrin chain band and that of GAPDH. The results are expressed as mean \pm S.D. of the percentage of control level obtained in three different experiments. (C) Representative up-regulation of $\alpha_{1}$ mRNA expression by IFN- $\gamma+$ TNF treatment. M, Haelll-digested $\phi \chi$ DNA as molecular size marker; lanes 1 to 3, LAN-5 cells; lanes 4 to 6 , GI-LI-N cells. Lanes 1 and 4, untreated NB cells; lanes 2 and 5 , NB cells treated with TNF $(200 \mathrm{IU} / \mathrm{ml})$; lanes 3 and 6 , NB cells treated with IFN- $\gamma+$ TNF $(1000 \mathrm{IU} / \mathrm{ml}+200 \mathrm{IU} / \mathrm{ml})$. 


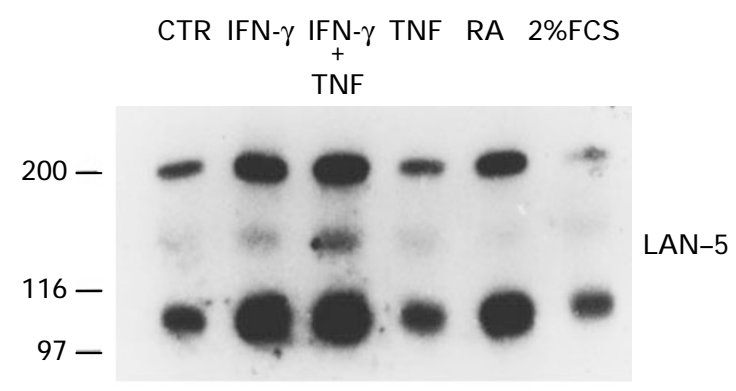

CTR RA IFN- $\gamma$ IFN- $\gamma$ TNF $2 \%$ FCS

$+$

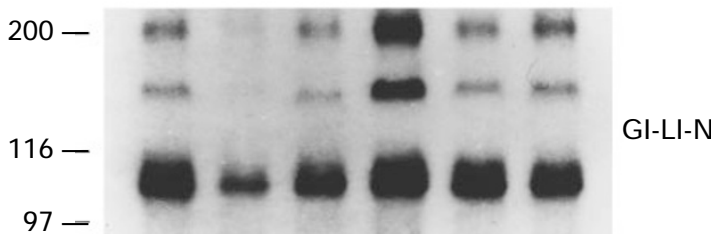

Figure 5 Integrin expression in LAN-3 and GI-LI-N cells treated for 5 days with differentiation promoting agents. Surface radioiodinated cell lysates of control and treated cells were immunoprecipitated using an anti $\beta_{1}$ antiserum as described in the Materials and Methods section. Molecular mass markers are in kilodaltons.

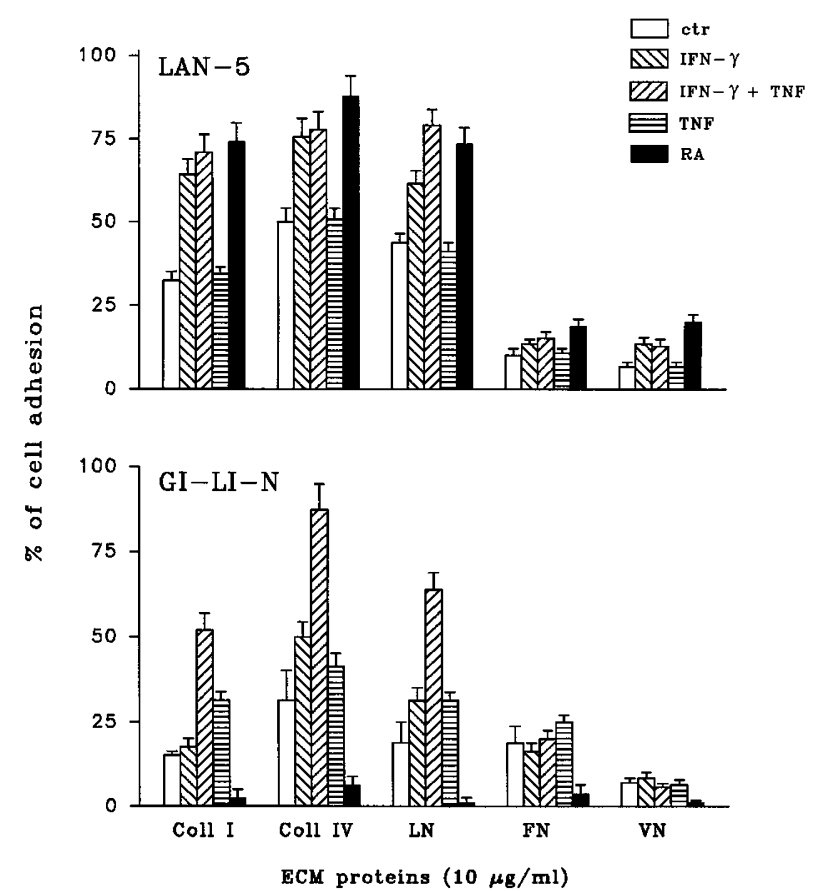

Figure 6 Adhesion properties of LAN-5 and GI-LI-N cells on ECM proteins after treatment with differentiating agents. Cell adhesion assays were carried out on control and treated NB cells as described in the Materials and methods section. The data are expressed as mean \pm S.D. of the percentage of treated and untreated attached cells in three independent experiments each done in triplicate.
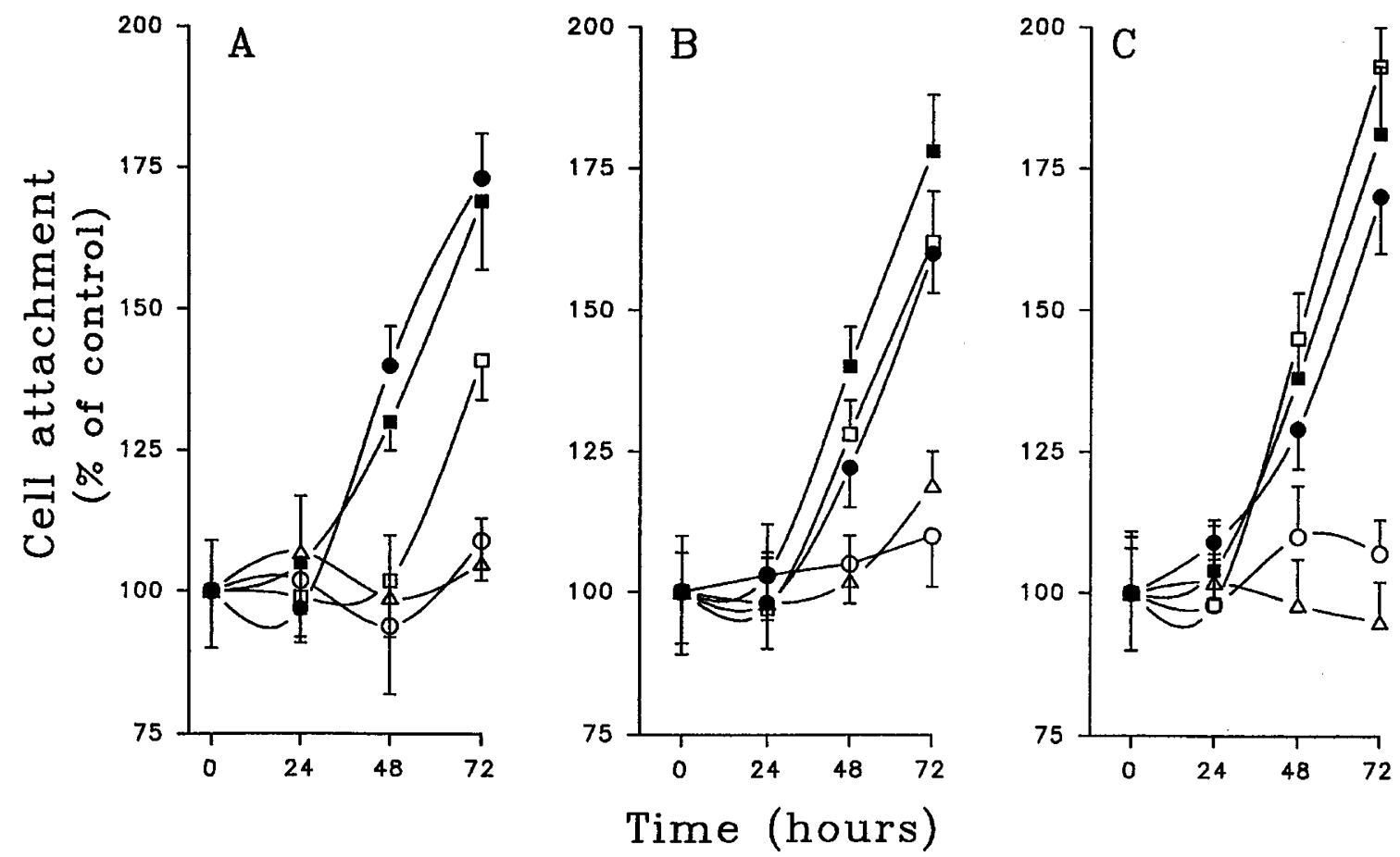

Figure 7 Time-dependent up-regulation of NB cell adhesion by differentiating agents. Cell adhesion assays were carried out on control and treated NB cells, at different times (Materials and Methods section). Data have been calculated as in Figure 6, but in this case, cell adhesion of untreated cells at each time-point has been taken as $100 \%$. (A) LAN-5 cells treated with IFN- $\gamma+$ TNF $(1000 \mathrm{IU} / \mathrm{ml}+200 \mathrm{IU} / \mathrm{ml})$; (B) LAN-5 cells treated with $3 \times 10^{-6} \mathrm{M} \mathrm{RA}$; (C) GI-LI-N cells treated with IFN- $\gamma+$ TNF $(1000 \mathrm{IU} / \mathrm{ml}+200 \mathrm{IU} / \mathrm{ml})-(\mathbf{\square})$ Colll; $(\square)$ Coll IV; $(\bullet)$ LN; $(\triangle)$ FN; $(O)$ VN 

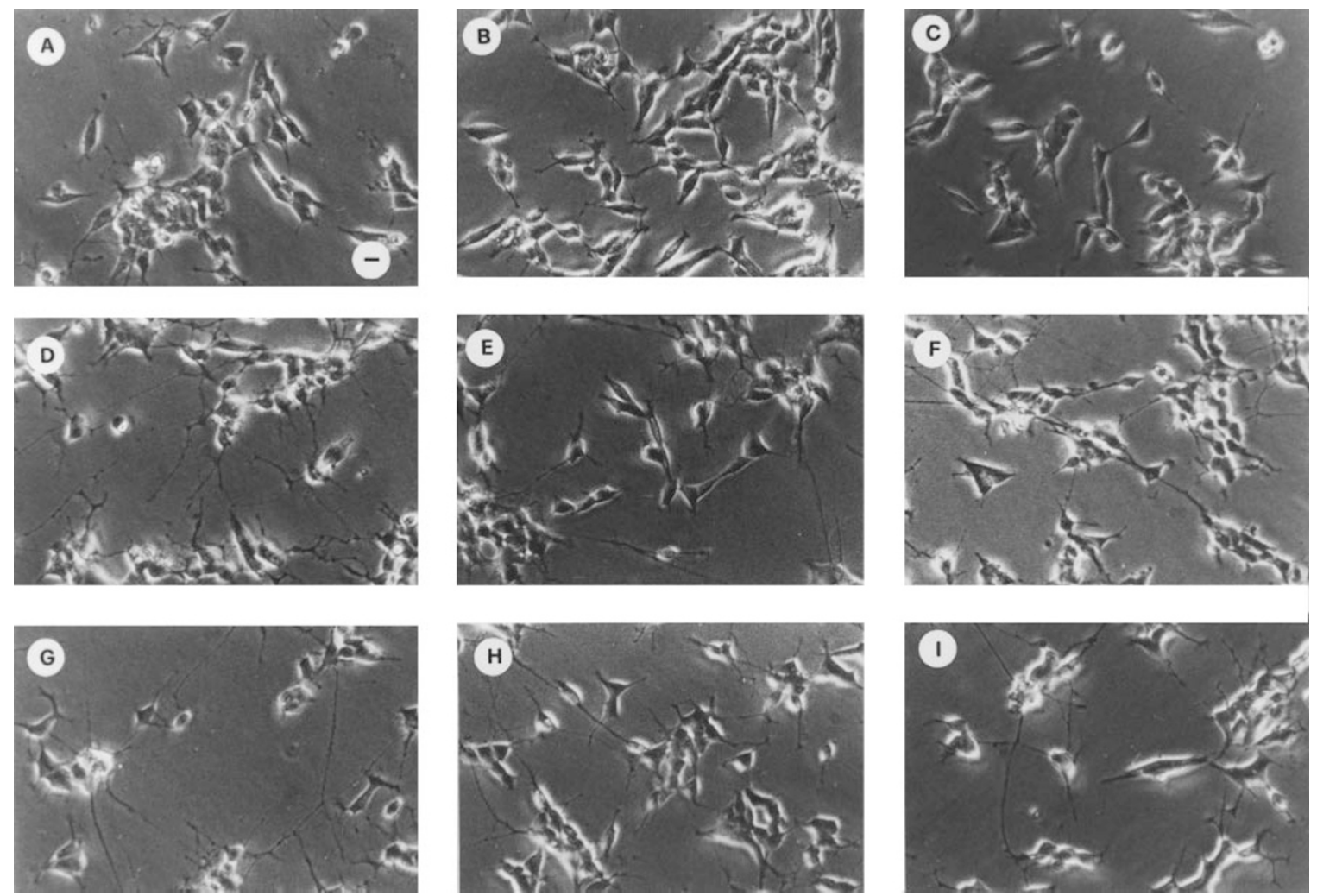

Figure 8 Induction of neurite extension by differentiating agents in LAN-5 cells. Untreated NB cells (A, B, C) or treated for 2 days with $1000 \mathrm{IU} / \mathrm{ml}+200 \mathrm{IU} / \mathrm{ml}$ of IFN$\gamma+\operatorname{TNF}(\mathbf{D}, \mathbf{E}, \mathbf{F})$ or with $3 \times 10^{-6} \mathrm{M}$ of RA $(\mathbf{G}, \mathbf{H}, \mathbf{I})$ were removed from the culture plates and seeded on coated wells in serum-free RPMI medium for $2 \mathrm{~h}$ at $37^{\circ} \mathrm{C}$. Phase contrast micrographs; bar corresponds to $100 \mu \mathrm{m}$. Substrates were coated with $10 \mu \mathrm{g} / \mathrm{ml}$ of $(\mathbf{A}, \mathbf{D}, \mathbf{G})$ laminin, (B, E, H) collagen I, and (C, F, I) collagen IV.

Table 2 IFN- $\gamma+$ TNF regulation of neurite outgrowth in NB cell lines

\begin{tabular}{lcccc}
\hline $\begin{array}{l}\text { Conditions }^{\mathbf{a}} \\
\text { IFN- } \gamma+\text { TNF }\end{array}$ & \multicolumn{2}{c}{$\begin{array}{c}\text { Neurite-bearing cells } \\
\text { b }\end{array}$} & \multicolumn{2}{c}{$\begin{array}{c}\text { Mean neurite length } \\
\text { per cell }\end{array}$} \\
pretreatment & \multicolumn{2}{c}{$\boldsymbol{\text { (\%) }})$} \\
no & LAN-5 & GI-LI-N & LAN-5 & GI-LI-N \\
\hline yes & $15 \pm 3$ & $3 \pm 1$ & $55 \pm 9$ & $47 \pm 10$ \\
\hline
\end{tabular}

${ }^{\mathrm{a} C}$ Culture dishes were coated with collagen I $(10 \mu \mathrm{g} / \mathrm{ml}) .{ }^{\mathrm{b}}$ Neurites, defined as process $>1$ cell diameter in length, were scored for single cells in 20 randomly chosen microscopic fields on each dish. The value presented are the means of triplicate dishes \pm standard deviations. ${ }^{M}$ Mean total length of neurite processes (including branches) measured for neurite-bearing cells

IFN- $\gamma+$ TNF induced the morphological and biochemical differentiation of both NB cell lines. Indeed, changes in the type and amount of intermediate filaments have been shown to accompany neuronal cell differentiation (Shaw and Weber, 1982). We observed that in LAN-5 cells RA induces high molecular weight neurofilament proteins, particularly in the phosphorylated form, typical of mature neurons (Shaw and Weber, 1982; Carden et al, 1987), as does the treatment with IFN- $\gamma+$ TNF. Moreover, data in chromaffin (Drubin et al, 1985) and NB cells (Ponzoni et al, $1992,1995)$ induced to differentiate indicated that MAPs are key regulators of neurite outgrowth. The enhanced expression in both cell lines of these cytoskeletal proteins by treatment with IFN- $\gamma+$ TNF and in LAN- 5 cells by RA treatment confirms the ability of these biological agents to induce true differentiation of NB cells. On the other hand, GI-LI-N cells treated with RA showed a slight but consistent down-modulation of almost all cytoskeletal proteins, thus confirming that cytoskeletal reorganization/disruption may occur during programmed cell death (Ponzoni et al, 1995; Thompson, 1995; Rozzo et al, 1997).

Adhesion of cells to matrix components is mostly mediated by integrin receptors (Hynes, 1992). These molecules, after binding to their specific ligands, cluster and promote the assembly of cytoskeletal proteins and, in turn, promote cell flattening on the substratum (Hynes, 1992; Burridge et al, 1988). Cells often display multiple integrins capable of interaction with a particular ECM protein ligand (Defilippi et al, 1991; Hemler, 1990). However, the precise mechanism(s) whereby signals from ECM proteins are transduced via integrins to the intracellular machinery controlling cell growth, behavior, differentiation, and apoptosis remains poorly defined (Juliano and Haskill, 1993; Clark and Brugge, 1995). There are many compelling examples of control of cell differentiation and gene expression through adhesive interactions with ECM (Defilippi et al, 1991; Dhawan et al, 1991; Kubota et al, 1992). Specifically, the extracellular matrix can influence various aspects of neuronal differentiation. Purified glycoproteins of the ECM such as laminin, collagens, and fibronectin have been shown to promote neurite outgrowth and survival in vitro (Davis et al, 1987; Tomaselli et al, 1987). The interactions of the 
glycoproteins with the cells are mediated by integrins, cell surface receptors, shown to be involved in attachment and neuronal process outgrowth (Tomaselli et al, 1987). Moreover, neurite outgrowth, a hallmark of neuronal cells, requires the interaction of the cell with the ECM (Tomaselli et al, 1986), and integrins have been shown to mediate this interaction (Tomaselli et al, 1987). In this paper, we provide evidence that real differentiation-promoting protocols induced specific up-regulation of integrin heterodimers in NB cells. Since biochemical features of NB cell differentiation are already detectable after 2 days of treatment with differentiation agents (Lanciotti et al, 1992; Ponzoni et al, 1992), our findings clearly indicate a role for integrin receptors in neuronal morphogenesis, thus ruling out their possible involvement in the triggering of NB maturation. Indeed, the increased expression of integrin receptors occurs within $48-72 \mathrm{~h}$ of IFN- $\gamma+$ TNF treatment, before neurite outgrowth can be morphologically appreciated (usually $72-96 \mathrm{~h}$ ); thus the kinetics of induction is compatible with the role of these receptors in neurite extension. These results confirm and extend our previous ones (Rozzo et al, 1993) and the data of Rossino et al (1991), demonstrating that the increased expression of integrin complex leads to increased neurite extension on specific matrix proteins. Furthermore, the fact that RA did not increase, as did the IFN- $\gamma+$ TNF treatment, the expression of $\alpha_{2} / \beta_{1}$ and $\alpha_{3} / \beta_{1}$ on LAN-5 cells, although it enhanced their capability to attach to ECM proteins, seems to confirm the overlapping and apparently redundant expression of integrin receptors on various cell types (Defilippi et al, 1991; Hemler, 1990).

It has also been suggested that growth cone-to substrate adhesion could be the rate-limiting step in neurite outgrowth (Turner et al, 1989; Zhang et al, 1993). This hypothesis is further supported by the findings of Rivas et al (1992), who observed that the addition of laminin to neuronal cultures grown on polylysine rapidly increases the rate of neurite extrusion by decreasing filopodial retraction, accelerating the outflow of organelles and microtubules into the adherent protrusions.

Mechanisms of extension are likely to be fairly similar in all cases of axon-like outgrowth. We have shown here that in NB cells, $\beta_{1}$ heterodimers play an essential role in differentiation-induced neurite outgrowth on ECM-coated substrata. We suggest that the role of integrins is to provide adequate traction at the growth cone and to allow for the cytoskeletal rearrangements necessary for the consolidation of the neuritic shaft by linking their cytoplasmic domains to the actin cytoskeleton.

\section{Materials and Methods}

\section{Chemicals}

Human recombinant interferon- $\gamma(\mathrm{IFN}-\gamma)$ and human recombinant tumour necrosis factor- $\alpha$ (TNF) were generous gifts of Boehringer Ingelheim (Milano, Italy); they were stored in aliquots $(30000 \mathrm{IU} / \mu \mathrm{l})$ at $-80^{\circ} \mathrm{C}$. All-trans-retinoic acid (RA) (Sigma Chemical Co., St. Louis, MO) was dissolved in absolute ethanol at the concentration of $10^{-2} \mathrm{M}$ and stored in aliquots at $-20^{\circ} \mathrm{C}$ (up to 1 week). All the other reagents of biochemical and molecular biology grade were obtained from Sigma.

\section{Cell cultures and treatments}

The human NB cell lines, LAN-5 (Seeger et al, 1982) and GI-LI-N (Longo et al, 1988) were maintained in the logarithmic growth phase in $75 \mathrm{~cm}^{2}$ plastic culture flasks (Corning, Bibby Sterlin, Ltd., Staffordshire, United Kingdom) in RPMI 1640 (Biochrom, Berlin, Germany) supplemented with $15 \%$ heat-inactivated FCS (Biochrom), sodium penicillin G $(50 \mathrm{IU} / \mathrm{ml})$, and streptomycin sulfate $(50 \mu \mathrm{g} / \mathrm{ml})$ (complete medium) at $37^{\circ} \mathrm{C}$ in a $5 \% \mathrm{CO}_{2}-95 \%$ air humidified incubator. Cells were split following treatment with 1 mM EDTA in Hanks' salts solution (Flow Laboratories, Milan, Italy), washed, counted, and replated in fresh complete medium. For induction of differentiation, cells were plated 2 days prior to the addition of inducing agents; the culture medium was replaced with fresh medium containing the inducing agents or their solvent control every other day. Cells were treated with $1000 \mathrm{IU} / \mathrm{ml} \mathrm{IFN}-\gamma$, and/or $200 \mathrm{IU} / \mathrm{ml} \mathrm{TNF}$, or $3 \times 10^{-6} \mathrm{M} \mathrm{RA}$, or starved in $2 \%$ FCS-complete medium for different times, as previously reported (Ponzoni et al, 1992, 1995; Rozzo et al, 1993).

\section{Cell morphology}

LAN- 5 cells $\left(5 \times 10^{5}\right)$ and GI-LI-N cells $\left(1 \times 10^{5}\right)$ were seeded into T-25 flasks with $5 \mathrm{ml}$ of culture medium and treated with the inducers as described above. From day 1 of treatment, 200 cells/culture from at least three different random areas of the flasks were examined daily with a phase contrast microscope (Olympus IMT-2).

\section{Immunofluorescence analysis}

Cytoskeletal proteins were detected as previously reported (Ponzoni et al, 1992), using mAbs with the following specificities: $M_{r} 200000$ neurofilaments (NF-200 Kda) and their phosphorylated forms (NF$200 \mathrm{Kda}-\mathrm{P}$ ), and microtubule associated proteins (MAP2, MAP5, and $\operatorname{MAP}(\tau)$ ) (Sigma-Aldrich, Milan, Italy). Briefly, cells were seeded at $2.5 \times 10^{4} / \mathrm{ml}$ into multiwell slides and incubated as described. At defined times the slides were fixed in methanol/acetone $(1 / 4, v / v)$ for $10 \mathrm{~min}$ at $-20^{\circ} \mathrm{C}$ and incubated for $1 \mathrm{~h}$ at $37^{\circ} \mathrm{C}$ in a humid chamber with $200 \mu \mathrm{l}$ of the appropriately diluted mAbs. After three washings with PBS for $3 \mathrm{~min}$ at room temperature, they were incubated again with fluorescein isothiocyanate-conjugated goat anti-mouse immunoglobulin (Sigma-Aldrich). Cells were washed twice, observed under a microscope (Leitz Orthoplan; Leitz GmbH, Wetzlar, Germany) equipped with a UV 100-W mercury bulb, and evaluated as described elsewhere (Ponzoni et al, 1992, 1995).

The exposure time of an automatic camera has been quantified at a magnitude of $\times 250$ on fields of comparable numbers of cells labeled with different antibodies and used as the indirect index of fluorescence intensity. The overall staining intensity was uniform in control and treated cultures. The following score was used (exposure time): infinite $(-) ; 60 \mathrm{~s}( \pm) ; 40 \mathrm{~s}(+) ; 20 \mathrm{~s}(++)$; less than $10 \mathrm{~s}(+++)$ (Ponzoni et al, 1992, 1995).

\section{DNA fragmentation assay}

After the RA treatment GI-LI-N cells were washed with ice-cold PBS, centrifuged at $1200 \mathrm{rpm}$ for $10 \mathrm{~min}$, and resuspended in lysis buffer consisting of $10 \mathrm{mM}$ Tris- $\mathrm{HCl}(\mathrm{pH} 8.0), 1 \mathrm{mM}$ EDTA, $0.2 \%$ Triton X100. Cell lysis was carried out for $5 \mathrm{~min}$ at $+4^{\circ} \mathrm{C}$ after brief vortexing. Cell lysates were then centrifuged at $13000 \mathrm{rpm}$ for $30^{\prime}$, at $+4^{\circ} \mathrm{C}$. Supernatants (S) were treated with $100 \mu \mathrm{g} / \mathrm{ml}$ Proteinase $\mathrm{K}$ and incubated o.n. at $37^{\circ} \mathrm{C}$. Pellets $(\mathrm{P})$ were resuspended in $10 \mathrm{mM}$ Tris$\mathrm{HCl}(\mathrm{pH} 8), 1 \mathrm{mM}$ EDTA, 0.5\% SDS, $100 \mu \mathrm{g} / \mathrm{ml}$ Proteinase $\mathrm{K}$, and incubated o.n. at $37^{\circ} \mathrm{C}$. Both $S$ and $P$ were phenol and chloroform 
extracted, then precipitated o.n. at $-20^{\circ} \mathrm{C}$ by adding $1: 100(\mathrm{v} / \mathrm{v}) 1 \mathrm{M}$ $\mathrm{MgCl}_{2}, 1: 10(\mathrm{v} / \mathrm{v}) 3 \mathrm{M}$ Na Acetate (pH 5.2) and 1 volume of isopropyl alcohol. DNA was then pelleted by centrifugation at $13000 \mathrm{rpm}$, for $20 \mathrm{~min}$, washed with 1 volume of $70 \%$ ethanol; and dried under vacuum. DNA was resuspended with $10 \mathrm{mM}$ Tris- $\mathrm{HCl}(\mathrm{pH} 8.0), 1 \mathrm{mM}$ EDTA buffer supplemented with $50 \mu \mathrm{g} / \mathrm{ml}$ RNase A and incubated for $2 \mathrm{~h}$ at $37^{\circ} \mathrm{C}$. Samples were then analyzed on $1.2 \%$ agarose ge electrophoresis, in $40 \mathrm{mM}$ Tris-acetate, $1 \mathrm{mM}$ EDTA (TAE) buffer (pH 8.0). One $\mu \mathrm{g}$ of Haelll-digested $\phi \chi$ DNA (Pharmacia Biotech, Uppsala, Sweden) or of 100 bp ladder (Boehringer Mannheim GmbH, Mannheim, Germany) was applied to each gel to provide molecular size markers.

\section{RNA extraction, and semiquantitative reverse transcription-polymerase chain reaction}

Total RNA was extracted from control or treated cells $\left(\sim 1 \times 10^{6}\right)$ using the guanidine-thiocyanate-chloroform method (Chomczynski and Sacchi, 1982). cDNA synthesis was made by priming different amounts of total RNA (ranging from 200 to $1 \mathrm{ng}$, the interval of linear signal generation by the two coamplified cDNAs, see below) with random hexamers by means of a commercial kit (Gene Amp RNA-PCR kit, Perking Elmer Corporation, Norwalk, CT) according to the suggested procedure. At the end of the synthesis, an integrin specific pair of primers together with two primers synthesized on the basis of the housekeeping gene glyceraldehyde 3-phosphate dehydrogenase (GAPDH) sequence were added in the same tube at the final concentration of $1 \mu \mathrm{M}$ each. PCR reactions were carried out according to the kit suggestions for 30 cycles, each comprised of the following three steps: $1 \mathrm{~min}$ at $94^{\circ} \mathrm{C}, 2 \mathrm{~min}$ at $58^{\circ}$ or $60^{\circ} \mathrm{C}, 3 \mathrm{~min}$ at $72^{\circ} \mathrm{C}$. These were followed by a final extension step of $10 \mathrm{~min}$ at $72^{\circ} \mathrm{C}$. The integrin specific primers, synthesized by standard procedure with an Applied Biosystem 391 DNA synthesizer (Foster City, CA), on the basis of the various human integrin CDNA published sequences were as follows: $\beta_{1}$ primers (forward 5'-GCGAAGGCATCCCTGAAAGT-3'; reverse 5'GGACACAGGATCAGGTTGGA); $\alpha_{1}$ primers (forward $5^{\prime}$-GAGCCTGGAACCTATTAAGC-3'; reverse 5'-CGAACTGTGATGTTCCTTTG-3'); $\alpha_{2}$ primers (forward 5'-GTGTGGACATCAGTCTGGAA-3'; reverse 5'CTGTGCACGATTGAAGGAAC-3'); $\alpha_{3}$ primers (forward $5^{\prime}$ GCTGTATCCCACGGAGATCA-3'; reverse $5^{\prime}$ GTCAGCCTCTCTGTCTCTGA-3'). The GAPDH specific primers were: forward 5'-TGAAGGTCGGAGTCAACGGAT-3'; reverse 5'CATGTGGGCCATGAGGTCC-3'.

PCR products were run on $2 \%$ agarose gel electrophoresis in TBE buffer (90 mM Tris- $\mathrm{HCl}$ (pH 8.3), $90 \mathrm{mM}$ Boric Acid, and $2 \mathrm{mM}$ EDTA) and stained with ethidium bromide. The gels were then photographed under UV transillumination. Two bands with the expected size of 982 base pairs (bp) for GAPDH and $663 \mathrm{bp}$, or $635 \mathrm{bp}$, or $618 \mathrm{bp}$, or 653 bp for $\beta_{1}, \alpha_{1}, \alpha_{2}$, or $\alpha_{3}$ integrin chains, respectively, were detected. Quantitation was made by scanning the photographs with the aid of the AppleScan program. For each time point, the ratio between the densitometric value of integrin and GAPDH bands was calculated in both treated and control cells and variations were expressed as percent of the corresponding control value.

\section{Cell surface radioiodination and immunoprecipitation}

Cells were grown for different times in the presence or absence of the various biological agents listed above, then harvested and surface labeled with $\mathrm{Na}\left[{ }^{125} \mathrm{I}\right]$, according to the procedure previously described (Rozzo et al, 1993). The anti $\beta_{1}$ rabbit polyclonal antiserum was generously provided by Dr. G. Tarone, University of Turin, Italy.
Immunoprecipitations were carried out as described (Rozzo et al, 1993). Briefly, the antibody was adsorbed onto protein G-agarose (Pierce, Rockford, IL, USA) by incubation for $1 \mathrm{~h}$ at $4{ }^{\circ} \mathrm{C}$ with rotation in $10 \mathrm{mM}$ Tris- $\mathrm{HCl}(\mathrm{pH} 8.5) 150 \mathrm{mM} \mathrm{NaCl}, 0.5 \%$ Tween 20, 0.1\% Renex, $0.01 \%$ ovalbumin, $2.5 \mathrm{mM} \mathrm{NaN}_{3}$ (PORT). These immunoadsorbents were incubated overnight at $4{ }^{\circ} \mathrm{C}$ with aliquots of radioiodinated cell lysates diluted in PORT, washed several times and eluted by boiling in Laemmli sample buffer (Laemmli, 1970). Samples were analyzed by SDS-PAGE on $7.5 \%$ polyacrylamide gels, followed by autoradiography on Hyperfilm MP (Amersham, Buckinghamshire, UK).

\section{Cell adhesion and neurite outgrowth assay}

Control and treated LAN-5 and GI-LI-N cells were metabolically labeled o.n. using $0.5 \mu \mathrm{Ci} / \mathrm{ml}$ of Trans $\left[{ }^{35} \mathrm{~S}\right.$ ] Label (ICN) (spec. at: $1125 \mathrm{Ci} / \mathrm{mmole}$ ) in Met-Cys-free RPMI 1640 (ICN) supplemented with $10 \%$ dialyzed FCS, sodium penicillin $\mathrm{G}(50 \mathrm{IU} / \mathrm{ml})$ and streptomycin sulfate $(50 \mu \mathrm{g} / \mathrm{ml})$. Floating and adherent cells were then harvested with ice cold PBS without $\mathrm{Ca}^{++}$and $\mathrm{Mg}^{++}$, washed twice, resuspended in RPMI 1640 without FCS, and seeded on 96 well-plates $\left(1 \times 10^{5}\right.$ cells/well) previously coated with the following ECM purified components, at the concentration of $10 \mu \mathrm{g} / \mathrm{ml}$ each, as previously described (Rozzo et al, 1993): Collagen type I (Coll I); collagen type IV (Coll IV); laminin (LN); fibronectin (FN); vitronectin (VN) (Sigma). Cells were allowed to adhere for $1 \mathrm{~h}$ at $37^{\circ} \mathrm{C}$ and then non-attached cells were washed out with PBS. Adherent cells were lysed with $200 \mu \mathrm{l}$ of $1 \%$ Triton X-100 in PBS for $30^{\prime}$ at $4^{\circ} \mathrm{C}$, the lysates transferred to scintillation vials and the radioactivity associated to the single samples was measured with a $\beta$-counter (Packard). Percentage of adherent cells was determined as the ratio bound of total radioactivity added. To check whether differences between control and treated cells were not due to difference in metabolic labeling, some adhesion experiments were performed using Cresyl violet as described (Rozzo et al, 1993) with comparable results.

Methods for coating dishes and for preparing cells for the neurite outgrowth assay were the same as described for cell attachment assay except that cells were not radioactively labeled. Neurite outgrowth was assayed in triplicate in $35 \mathrm{~mm}$ dishes coated as for the attachment assay, using serum-free RPMI medium with or without IFN- $\gamma+$ TNF $\left(1000 \mathrm{IU} / \mathrm{ml}+200 \mathrm{IU} / \mathrm{ml}\right.$ ) as indicated. After incubation at $37^{\circ} \mathrm{C}$ for $12 \mathrm{~h}$, cells were fixed with $2.5 \%$ glutaraldehyde (Sigma) for $30 \mathrm{~min}$ and rinsed twice with PBS. Twenty microscopic fields were chosen randomly from each dish and single cells were scored. Cells with at least one process greater than one cell diameter were counted as neurite-bearing cells.

\section{Acknowledgements}

The authors wish to thank $\mathrm{G}$. Tarone for anti $\beta_{1}$ antiserum, G.R. Adolf (Boehringer, Vienna) for human recombinant IFN- $\gamma$, L. Raffaghello for expert technical assistance, E. Accettulli and P.M. Melis for editing. V. Pistoia, P.G. Montaldo, M.V. Corrias and C. Grossi for helpful comments. This work was supported in part by Associazione Italiana Ricerca sul Cancro (AIRC) by Associazione Italiana Neuroblastoma, and by Ricerca Corrente Ministeriale Gaslini.

\section{References}

Abemayor E and Sidell N (1989) Human neuroblastoma cell lines as models for the in vitro study of neoplastic and neuronal cell differentiation. Environ. Health Perspect. 80: 3-15 
Adams J and Watt F (1993) Regulation of development and differentiation by the extracellular matrix. Development 117: 1183-1198

Biedler JL, Helson L and SpenglerBA (1973) Morphology and growth, tumorigenicity, and cytogenetics of human neuroblastoma cells in continuous culture. Cancer Res. 33: 2643-2652

Blau H and Baltimore D (1991) Differentiation requires continuous regulation. J. Cell Biol. 112: $781-783$

Brooks PC, Montgomery AMP, Rosenfeld M, Reisfeld RA, Hu T, Klier G and Cheresh DA (1994) Integrin $\alpha_{v} \beta_{3}$ antagonists promote tumor regression by inducing apoptosis of angiogenic blood vessels. Cell 79: 1157-1164

Burridge K, Fath K, Kelly T, Nuckolls G and Turner C (1988) Focal adhesion: transmembrane junctions between the extracellular matrix and the cytoskeleton. Annu. Rev. Cell Biol. 4: 487-525

Carden MJ, Troianowsky JQ, Schlaepfer WW and Lee V (1987) Two stage expression of neurofilament polypeptides during rat neurogenesis with early establishment of adult phosphorylation patterns. J. Neurosci. 7: 3489-3504

Chomczynski P and Sacchi N (1982) Single step method of RNA isolation by guanidinium thiocyanate-phenol-chloroform extraction. Anal. Biochem. 162 $156-159$

Ciccarone V, Spengler BA, Meyers MB, Biedler JL and Ross RA (1989) Phenotipic diversification in human neuroblastoma cells: expression of distinct neural crest lineages. Cancer Res. 49: 219-225

ClarkEA and Brugge JS (1995) Integrins and signals transduction pathways; the road taken. Science 268: 233-239

Cooper MJ, Hutchins GM, Mennie RJ and Israel MA (1990a) Beta-2-microglobulin expression in embryonal neuroblastoma reflects its developmental regulation. Cancer Res. 70: 3694-3700

Cooper MJ, Hutchins GM, Choen PS, Helman LJ, Mennie RJ and Israel MA (1990b) Human neuroblastoma tumor cell lines correspond to the arrested differentiation of chromaffin adrenal medullary neuroblasts. Cell Growth Diff. 1: 149-159

Cushing $\mathrm{H}$ and Wolbach BB (1927) The transformation of a malignant paravertebral sympathicoblastoma into a benign ganglioneuroma. Am. J. Pathol. 3: 203-207

Davis GE, Blaker SN, Engvall E, Varon S, Manthorpe M and Gage F (1987) Human amnion membrane serves as a substratum for growing axons in vitro and in vivo. Science 236: 1106-1109

De Bernardi B, Rogers D, Carli M, Madon E, De Laurentis T, Bagnulo S, Di Tullio M Paolucci G and Pastore G (1987) Localized neuroblastoma. Cancer 60: 1066 1072

Dedhar S, Robertson K and Gray V (1991) Induction of expression of the $\alpha_{v} \beta_{1}$ and $\alpha_{v} \beta_{3}$ integrin heterodimers during retinoic acid-induced neuronal differentiation of murine embryonal carcinoma cells. J. Biol. Chem. 266: 21846-21852

Dedhar S, Haqq C and Gray V (1989) Specific overproduction of very late antigen 1 integrin in two human neuroblastoma cell lines selected for resistance to detachment by an Arg-Gly-Asp-containing synthetic peptide. J. Biol. Chem. 264: $4832-4836$

Defilippi P, Truffa G, Stefanuto G, Altruda F, Silengo L and Tarone G (1991) Tumo necrosis factor $\alpha$ and interferon gamma modulate the expression of the vilitronectin receptor (integrin $\beta_{3}$ ) in human endothelial cells. J. Biol. Chem. 266 $7638-7645$

Dhawan J, Lichtler AC, Rowe DW and Farmer SR (1991)Cell adhesion regulates proalpha 1 (I) collagen mRNA stability and transcription in mouse fibroblasts. J. Biol. Chem. 266: 8470-8475

Drubin DG, Feinstein SC, Shooter EM and Kirschner MW (1985) Nerve growth facto induced neurite outgrowth in PC12 cells involves the co-ordinate induction of microtubule assembly promoting factors. J. Cell. Biol., 101: 1799-1808

Frisch SM and Francis H (1994) Disruption of epithelial cell-matrix interactions induces apoptosis. J. Cell Biol. 124: 619-626

Hanada M, Krajewski S, Tanaka S, Cazals-Hatem D, Spengler BA, Ross RA, Biedler JL and Reed JC (1993) Regulation of Bcl-2 oncoprotein levels with differentiation of human neuroblastoma cells. Cancer Res. 53: 4978-4986

Hass D (1988) Complete pathologic maturation and regression of the stage IV-S neuroblastoma without treatment. Cancer 62: 818-825

Heino J, Ignotz RA, Hemler ME, Crouse C and Massague J (1989) Regulation of cell adhesion receptors by transforming growth factor- $\beta$. J. Biol. Chem. 264: $380-$ 388

Hemler ME (1990) VLA proteins in the integrin family: structures, functions and their role in leukocytes. Annu. Rev. Immunol. 8: 365-400

Hynes RO (1992) Integrins: versatility, modulation and signaling in cell adhesion. Cell 69: $11-25$
Kubota S, Tashiro K and Yamada Y (1992) Signaling site of laminin with mitogenic activity. J. Biol. Chem. 267: 4285-4288

Ingber D (1993) Cellular tensegrity: defining new rules of biological design that govern the cytoskeleton. J. Cell Sci. 104: 613-623

Jensen LM, Zhang Y and Shooter EM (1992) Steady-state polypeptide modulation associated with nerve growth factor (NGF)-induced terminal differentiation and NGF deprivation-induced apoptosis in human neuroblastoma cells. J. Biol. Chem. 267: 19325-19333

Juliano RL and Haskill S (1993) Signal transduction from the extracellular matrix. J. Cell Biol. 120: $577-585$

Laemmli UK (1970) Cleavage of structural protein during the assembly of the head of bacteriophage T4. Nature 227: 680-682

Lanciotti M, Montaldo PG, Folghera S, Lucarelli E, Cornaglia-Ferraris P and Ponzoni M (1992) A combined evaluation of biochemical and morphological changes during human neuroblastoma cell differentiation. Cell Mol. Neurobiol. 12: $225-$ 240

Longo L, Christiansen H, Christiansen NM, Paulsen $\mathrm{P}$, Cornaglia-Ferraris $\mathrm{P}$ and Lampert $\mathrm{F}$ (1988) N-myc amplification at chromosome band 1p32 in neuroblastoma cells as investigated by in situ hybridization. J. Cancer Res. Clin. Onocl. 114: 636-640

Menko AS and Boettiger D (1987) Occupation of the extracellular matrix receptor, integrin, is a control point for myogenic differentiation. Cell 51: 51-57

Montaldo PG, Carbone R, Corrias MV, Cornaglia-Ferraris P and Ponzoni M (1994) Synergistic differentiation-promoting activity of interferon- $\gamma$ and tumor necrosis factor- $\alpha$ : Role of receptor regulation on human neuroblasts. J. Natl. Cancer Inst. 86: $1694-1701$

Piacentini M, Annichiarico-Petruzzelli M, OliverioS, Piredda L, Biedler Jand Melino G (1992) Phenotype-specific 'tissue' transglutaminase regulation in human neuroblastoma cells in response to retinoic acid: correlation with cell death by apoptosis. Int. J. Cancer 52: 271-278

Ponzoni M, Bocca P, Chiesa V, Decensi A, Pistoia V, Raffaghello L, Rosso C and Montaldo PG (1995) Differential Effects of N-(4-Hydroxyphenyl)retinamide and retinoic acid on neuroblastoma cells: apoptosis versus differentiation. Cancer Res. 55: 853-861

Ponzoni M, Casalaro A, Lanciotti M, Montaldo PG and Cornaglia-Ferraris P (1992) The combination of $\gamma$-interferon and tumor necrosis factor causes a rapid and extensive differentiation of human neuroblastoma cells. Cancer Res. 52: 931 939

Reichardt LF and Tomaselli KJ (1991) Extracellular matrix molecules and their receptors: function in neural development. Annu. Rev. Neurosci. 14: 531-570

Rivas RJ, Burmeister DW and Goldberg DJ (1992) Rapid effects of laminin on the growth cone. Neuron 8: 107-115

Ross RA, Spengler BA and Biedler JL (1983) Co-ordinate morphological and biochemical interconversion of human neuroblastoma cells. J. Natl. Cancer Inst. 71: $741-747$

Rossino P, Defilippi $P$, Silengo $L$ and Tarone G (1991) Up-regulation of integrin $\alpha_{1} / \beta_{1}$ in human neuroblastoma cells differentiated by retinoic acid: correlation with increased neurite outgrowth response to laminin. Cell Regulation 2: 1021-1033

Rozzo C, Ratti P, Ponzoni M and Cornaglia-Ferraris P (1993) Modulation of $\alpha_{1} \beta_{1}, \alpha_{2}$ $\beta_{1}$ and $\alpha_{3} \beta_{1}$ integrin heterodimers during human neuroblastoma cell differentiation. FEBS Letter 332: 263-267

Rozzo C, Chiesa V, Caridi G, Pagnan G and Ponzoni M (1997) Induction of apoptosis in human neuroblastoma cells by abrogation of integrin-mediated cell adhesion. Int. J. Cancer 70: 688-698

Seeger RC, Danon YL, Rayner SA and Hoover F (1982) Definition of a Thy-1 determinant of human neuroblastoma, glioma, sarcoma and teratoma cells with a monoclonal antibody. J. Immunol. 128: 983-989

Shaw $G$ and Weber (1982) Differential expression of neurofilament triplet proteins in brain development. Nature 298: 277-279

Sidell N (1982) Retinoic acid-induced growth inhibition and morphologic differentiation of human neuroblastoma cells in vitro. J. Natl. Cancer Inst. 68 : $589-593$

Stoker M, O'Neil C, Berryman S and Vaxman V (1968) Anchorage and growth regulation in normal and virus-transformed cells. Int. J. Cancer 3: 683693

Thompson CB (1995) Apoptosis in the pathogenesis and treatment of disease. Science 267: 1456-1462 
Tomaselli KJ, Damsky CH and Reichardt LF (1987) Interaction of a neuronal cell line (PC12) with laminin, collagen IV, and fibronectin: identification of integrin-related glycoprotein involved in attachment and process outgrowth. J. Cell Biol. 105: $2347-2358$

Tomaselli KJ, Reichardt LF and Bixby JL (1986) Distinct molecular interaction mediate neuronal process outgrowth on non-neuronal cell surfaces and extracellular matrices. J. Cell Biol. 103: 2659-2672

Tsokos M, Scarpa S, Ross R and Triche TJ (1987) Differentiation of human neuroblastoma recapitulates neural crest development. Am. J. Pathol. 128: $484-496$

Turner DC, Flier LA and Carbonetto S (1989) Identification of a cell surface protein involved in PC12 cell-substratum adhesion and neurite outgrowth on laminin and collagen. J. Neurosci. 9: 3287-3296

Wuarin L, Verity MA and Sidell N (1991) Effects of interferon- $\gamma$ and its interaction with retinoic acid on human neuroblastoma differentiation. Int. J. Cancer 48: $136-$ 141

Zhang Z, Tarone $G$ and Turner DA (1993) Expression of integrin $\alpha_{1} \beta_{1}$ is regulated by Nerve Growth Factor and Dexamethasone in PC12 cells. J. Biol. Chem. 268: $5557-5565$ 